\title{
In Search for Anti-Aging Strategy: Can We Rejuvenate Our Aging Stem Cells?
}

\author{
Anna Meiliana ${ }^{1,2, *}$, Nurrani Mustika Dewi², Andi Wijaya ${ }^{2,3}$ \\ ${ }^{1}$ Postgraduate Program in Clinical Pharmacy, Padjadjaran University, Jl. Eijkman No.38, Bandung, Indonesia \\ ${ }^{2}$ Prodia Clinical Laboratory, Jl. Cisangkuy No.2, Bandung, Indonesia \\ ${ }^{3}$ Postgraduate Program in Clinical Biochemistry, Hasanuddin University, J1. Perintis Kemerdekaan Km.10, Makassar, Indonesia \\ *Corresponding author. E-mail: anna.meiliana@prodia.co.id
}

Received date: Apr 28, 2015; Revised date: May 21, 2015; Accepted date: May 23, 2015

\section{Abstract}

$\mathrm{B}$ ACKGROUND: Recent evidence suggested that we grow old partly because of our stem cells grow old as a result of mechanisms that suppress the development of cancer over a lifetime. We believe that a further, more precise mechanistic understanding of this process will be required before this knowledge can be translated into human anti-aging therapies.

CONTENT: A diminished capacity to maintain tissue homeostasis is a central physiological characteristic of aging. As stem cells regulate tissue homeostasis, depletion of stem cell reserves and/or diminished stem cell function have been postulated to contribute to aging. It has further been suggested that accumulated DNA damage could be a principal mechanism underlying age-dependent stem cell decline. It is interesting that many of the rejuvenating interventions act on the stem cell compartments, perhaps reflecting shared genetic and biochemical pathways controlling stem cell function and longevity. Strategy to slow down the aging processes is based on caloric restriction refers to a dietary regimen low in calories but without undernutrition. Sirtuin (SIRT) 1 and 3, increases longevity by mimicking the beneficial effects of caloric restriction. SIRT3 regulates stress-responsive mitochondrial homeostasis, and more importantly, SIRT3 upregulation rejuvenates aged stem cells in tissues. Resveratrol (3,5,4'-trihydroxystilbene), a natural polyphenol found in grapes and wine, was the most powerful natural activator of SIRT1. In fact, resveratrol treatment has been demonstrated to rescue adult stem cell decline, slow down bodyweight loss, improve trabecular bone structure and mineral density, and significantly extend lifespan.

SUMMARY: Tissue-specific stem cells persist throughout the entire lifespan to repair and maintain tissues, but their self-renewal and differentiation potential become dysregulated with aging. Given that adult stem cells are thought to be central to tissue maintenance and organismal survival, SIRT3 may promote organismal longevity by maintaining the integrity of tissue-specific stem cells.

KEYWORDS: rejuvenation, aging, stem cell, DNA damage, sirtuin activator

Indones Biomed J. 2015; 7(2): 57-72

\section{Introduction}

Aging is characterized by a progressive loss of physiological integrity, leading to impaired function and increased vulnerability to death. This deterioration is the primary risk factor for major human pathologies, including cancer, diabetes, cardiovascular disorders, and neurodegenerative diseases.(1) Aging, which we broadly define as the timedependent functional decline that affects most living organisms, has attracted curiosity and excited imagination throughout the history of humankind. For thousands of years humanity has searched for the fountain of youth. In the 16th century the Spanish explorer Juan Ponce de León, first Governor of Puerto Rico, searched for the fountain of youth in the legendary land of Florida, specifically in the waters of Bimini, but without success. This quest continues, although all living species on our planet are designed to age. 
The underlying cause of aging remains one of the central mysteries of biology. Recent studies in several different systems suggest that not only may the rate of aging be modified by environmental and genetic factors, but also that the aging clock can be reversed, restoring characteristics of youthfulness to aged cells and tissues.(3) Aging is associated with a gradual loss of homeostatic mechanisms that maintain the structure and function of adult tissues. A major challenge of aging research has been to distinguish the causes of cell and tissue aging from the myriad of changes that accompany it. One of the hallmarks of cellular aging is an accumulation of damaged macromolecules such as DNA, proteins, and lipids. These become chemically modified by reactive molecules, such as free radicals, that are generated during normal cellular metabolism and whose production increases with age.(4)

At the cellular level, aging induces many potentially interconnected defects, including DNA damage in the nucleus and mitochondria, mitochondrial dysfunction leading to increased production of reactive oxidative species (ROS) and decreased production of ATP, oxidative damage to proteins and other macromolecules in cells, protein misfolding and aggregation, protein glycation, the induction of proinflammatory cytokines, telomere shortening, and cell senescense.(1) These will impact mitotically active tissues over time by triggering stem cell depletion by senescence and apoptosis (e.g., intestinal stem cell, hematopoietic stem cell (HSC), mesenchymal stem cell (MSC), etc.), and postmitotic tissues by causing cellular dysfunction and loss (e.g., muscle, heart, and brain). Beyond tissue-autonomous aging, it is now clear that the brain helps govern aging of many organs $(5,6)$, i.e., dysfunction in the hypothalamus will exert systemic effects leading to functional decline and damage to cells and organs.(7)

Stem cells, through their regenerative ability, maintain tissue homeostasis during an individual's lifespan. However, stem cell-associated mechanisms of tissue repair become impaired with aging. Very interestingly, a recent study demonstrated that Sirtuin (SIRT)3, which is highly expressed in $\mathrm{HSC}$, is not essential for tissue repair at a young age under physiological conditions; however, it is crucial at an old age. Moreover, it is important to highlight that induced SIRT3 overexpression, which is suppressed with aging, significantly improves aged HSC's regenerative power.(8) The recent implication of a role for SIRT in the field of regenerative medicine also suggests their possible application in stem cell therapy. The scientific community has not yet found the fountain of youth; however, the SIRT story thus far seems the closest to Ponce de León's water of Bimini.(2)

\section{Stem Cell Hypothesis of Aging}

The aging process is an inevitable consequence of life. As a result of exposure to intrinsic, as well as extrinsic aging factors, cellular aging is triggered by gradually accumulating DNA damage and epigenetic changes in DNA's structure.(911) Thus, aging could be envisioned at the cellular level as a result of altered cell function in response to changes in the DNA structure that directly affect proper gene expression. (12) With age, there is a gradual decline in the regenerative properties of most tissues due to a combination of agedependent changes in tissue-specific stem cells and in the environmental cues that promote those cells to participate in tissue maintenance and repair.(13) These rare and specialized adult stem cell (ASC) are required for tissue replacement throughout the human lifespan, and appear to be characterized by a few specific physiological and biochemical properties, particularly the capacity for selfrenewal.(14-17)

Mechanisms that suppress the development of cancer, such as senescence and apoptosis, which rely on telomere shortening and the activities of p53 and p16INK4a may also induce an unwanted consequence: a decline in the replicative function of certain stem cells types with advancing age. This decrease regenerative capacity appears to pointing to the "stem cell hypothesis of aging".(17) Many of the pathophysiological conditions afflicting the elderly, such as anemia, sarcopenia, and osteoporosis, suggest an imbalance between cell loss and renewal. The fact that homeostatic maintenance and regenerative potential of tissues wane with age has implicated stem cell decline as a central player in the aging process. However, the degree to which aging is attributable to stem cell dysfunction or instead reflects a more systemic degeneration of tissues and organs will likely differ substantially between different tissues and their resident stem cells.(18)

Many of the pathophysiological conditions afflicting the elderly, such as anemia, sarcopenia, and osteoporosis, suggest an imbalance between cell loss and renewal. The fact that homeostatic maintenance and regenerative potential of tissues wane with age has implicated stem cell decline as a central player in the aging process. However, the degree to which aging is attributable to stem cell dysfunction or instead reflects a more systemic degeneration of tissues and organs will likely differ substantially between different tissues and their resident stem cells.(18)

ASC populations maintain highly differentiated but short-lived cells such as blood, intestinal epithelium cells, and sperm throughout life. Upon division of stem cells, 
daughter cells must either self-renew to preserve stem cell identity or commit to differentiation. The balance between stem cell self-renewal and differentiation is critical to tissue homeostasis, with disruption of this balance leading to tumorigenesis (caused in some cases by stem cell overproliferation) or tissue degeneration (caused by stem cell depletion). A decline in the function of ASC and their supportive niches has been proposed to contribute to tissue aging, although the underlying mechanisms remain enigmatic. $(19,20)$ Tissue aging has been proposed to have arisen as a tumor suppressor mechanism (21-24), in which tumor suppressor activity reduces stem cell function in later stages of life, preventing tumorigenesis but reducing tissue regenerative capacity.

Most studies of the effects of aging on ASC focus upon the HSC and the age-related changes they undergo are well documented. We have attempted to summarize the age-related changes affecting HSCs. HSC numbers do not decrease with age rather, the proportion of Cluster of Differentiation (CD) $34^{+} / \mathrm{CD} 38$ or $\mathrm{Lin} / \mathrm{CD} 34^{+} / \mathrm{CD} 38 /$ $\mathrm{CD} 90^{+} / \mathrm{CD} 45 \mathrm{RA}$ increases in the elderly bone marrow of humans and mice, respectively, $(25,26)$ but these cells show a number of functional differences to their youthful counterparts. The increasing preference for myeloid over lymphoid differentiation has already been noted (27), but why this should occur is not completely understood. One suggestion is that the relative percentage of myeloid committed progenitors increases with age at the expense of lymphoid committed cells although we do not know if such bias is due to an intrinsic change in the properties of HSC or if it simply arises because HSC that were committed to a myeloid fate earlier in the life of the individual become more numerous.

Epigenetic changes in HSCs as a function of age have been recorded by other workers. To identify transcriptional changes in aged HSCs that correlate with their known functional deficit. Most of the genes that were consistently upregulated in aged HSCs belonged to categories previously linked to aging in general such as nitric oxidemediated signal transduction systems, protein folding, and inflammatory responses; however, genes undergoing substantial downregulation with age tended to be those involved in the preservation of genomic integrity such as chromatin remodeling and DNA repair.(18,28)

Stem cells must change their properties throughout life to match the changing growth and regeneration demands of tissues. Stem cells divide rapidly during fetal development to support rapid growth. By young adulthood, growth has slowed or ceased in mammalian tissues and most stem cells are quiescent most of the time, intermittently dividing to maintain tissue homeostasis. In old adults, stem cells increase gate-keeping tumor suppressor expression. This may reduce the incidence of cancer in aging tissues, but also reduces regenerative capacity.(29-31) These changes in stem cells likely reflect regulation by heterochronic genes, genes whose expression changes over time in a way that causes temporal changes in stem cell function.(32-33)

ASCs are known to be mostly quiescent and to rarely enter cell cycle.(34) The few exceptions, such as intestinal stem cells $(35)$, are the subject of debate. $(36,37)$ It has been postulated that quiescence protects stem cells from incurring damage during cell division and plays a necessary role in their lifetime maintenance. Nonetheless, when faced with major tissue loss or damage, stem cells exit their quiescent state and enter the cell cycle to proliferate and generate large numbers of differentiated progenies. These properties may be shared by cancer stem cells.(38)

Recently, the progeroid phenotype of the mitochondrial DNA (mtDNA) mutator mice has been, at least partly, attributed to embryonic-onset dysfunction of somatic stem cells.(39) Ahlqvist and coworkers demonstrated that development of neural and hematopoietic progenitor cells of the mtDNA mutator mice is already affected during fetal development, and that neural stem cells showed decreased abundance in vivo as well as reduced self-renewal in vitro. (40) Their data suggest that mtDNA mutagenesis affects the quality and quantity of stem cells and interferes with the maintenance of the quiescent state, which is important for reconstitution capacity and long-term sustenance of somatic stem cells.(41)

The observation that treatment with the antioxidant $\mathrm{N}$-acetyl cysteine restores the self-renewal ability of neural progenitor cells in mtDNA mutator mice (65) implies that subtle changes in cellular redox state or ROS levels are important for the regulation of somatic stem cell function (Figure 1). Mitochondrial activity, tissue growth, and metabolic rates during development can also influence life span and the rates of cellular aging at later stages of life. (42) Thus, the aging of stem cells cannot be considered in isolation but rather in the context of temporal changes in stem cell and tissue properties that occur throughout life. Like all cells, stem cell aging is determined partly by the accumulation of damage over time. Declines in stem cell function during aging can be precipitated by telomere shortening, DNA damage, and mitochondrial damage.(4345) Stem cell aging can be slowed by dietary restriction (46-49) and by exposure to humoral factors from a young parabiont (sharing circulation with an old mouse) $(50,51)$. 


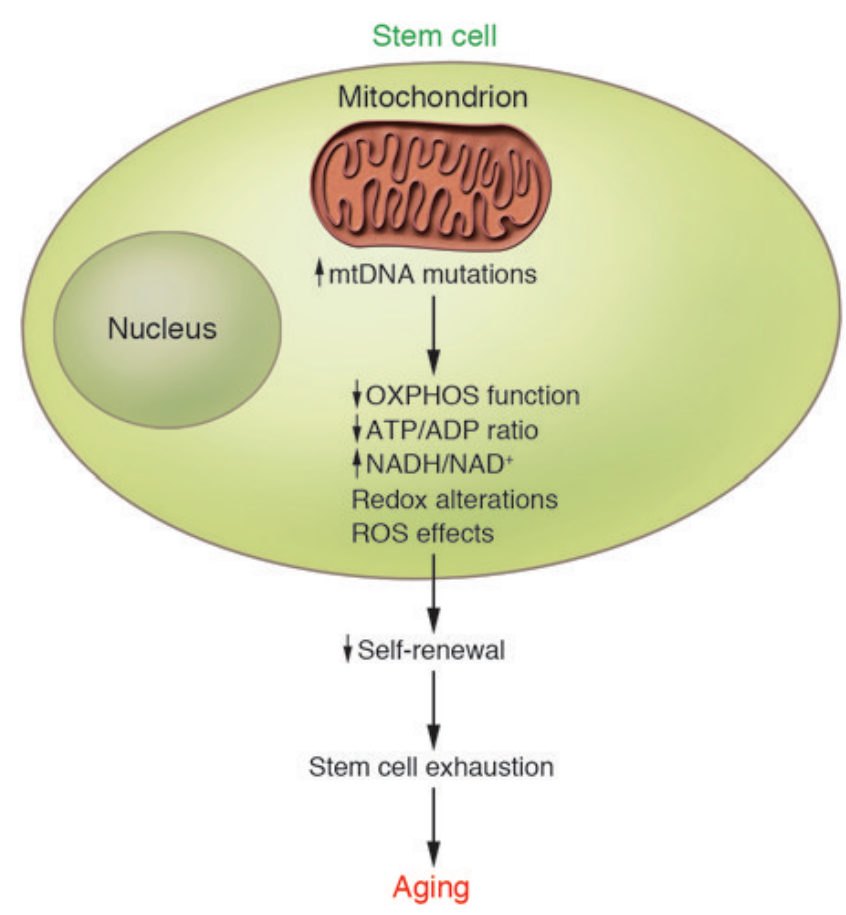

Figure 1. Model for mtDNA mutations in the stem cell hypothesis of aging.(41) (Adapted with permission from American Society for Clinical Investigation).

\section{Stem Cell Niche Maintenance During} Homeostasis and Regeneration

Most mammalian adult tissues contain resident stem cells, which proliferate to compensate for tissue loss throughout the life of the organism. They possess remarkable proliferative capacity, allowing them to engage in massive and repetitive regenerative activities in response to tissue damage. A subset of tissue-specific ASC persists in the quiescent state for prolonged periods of time.(52) Whereas quiescence is not an essential characteristic that defines stem cells, dysregulation and loss of quiescence often results in an imbalance in progenitor cell populations ultimately leading to stem cell depletion.(53) As a result, tissue replenishment is affected during homeostasis and following damage. Thus, deciphering the regulation of quiescence will contribute much to our understanding of how tissue regeneration is accomplished in physiological and pathological settings and may lead to new therapeutic strategies for tissue maintenance or repair.(54)

As demonstrated by studies of different stem cell compartments, one of the consequences of inhibiting essential signaling pathways that maintain the quiescent state is the premature activation or differentiation of stem cells. This is often followed by the exhaustion of the stem cell pool and results in impaired tissue homeostasis and regeneration, highlighting the importance of maintaining stem cell quiescence for tissue and organismal health. In some tissues, quiescent stem cells seem to serve as a reserve pool of stem cells and are only called into action upon tissue injury.

Recent advances in ASC isolation have provided insights into the epigenetic, transcriptional and posttranscriptional control of quiescence and suggest that quiescence is an actively maintained state in which signaling pathways are involved in maintaining a poised state that allows rapid activation. Deciphering the molecular mechanisms regulating ASC quiescence will increase our understanding of tissue regeneration mechanisms and how they are dysregulated in pathological conditions and in aging. In addition to the intrinsic mechanisms that regulate stem cell quiescence, the stem cell niche (that is, a specific microenvironment that surrounds stem cells and has important regulatory functions) is essential for stem cell maintenance, including the maintenance of quiescence. $(54,55)$

A defining feature of stem cells is their ability to continuously maintain a balanced number of stem cells (self-renewal) while being able to generate specialized progeny (differentiation). An additional feature of stem cells is their ability to migrate. Therefore, stem cells are unique as they are able to balance four possible fates within a single cell: quiescence, migration, proliferation, and differentiation. These fate decisions are made in the context of the supporting stroma cells they adhere to, also referred to as the niche.(56) ASCs are found in specific locations or niches that are ultimately responsible for the maintenance of stem cell populations, their controlled proliferation and the differentiation of their progeny into multiple cellular lineages. Niches provide stem cells specific signals and physical support in the form of specialized cells and/or extracellular matrix (ECM).(57-61)

The bone marrow niche has mystified scientists for many years, leading to widespread investigation to shed light into its molecular and cellular composition. Considerable efforts have been devoted toward uncovering the regulatory mechanisms of HSC niche maintenance. Hematopoiesis is a continuous process of blood-cell production occurring through the orchestrated proliferation, self renewal and differentiation of HSCs in the bone marrow followed by egress of mature progeny into the circulating blood.(62-65) HSCs are the only cells capable of producing all blood cell lineages throughout life.(66) Within the bone marrow exists a tightly controlled local microenvironment, or niche, that regulates the quiescence, proliferation and differentiation of 


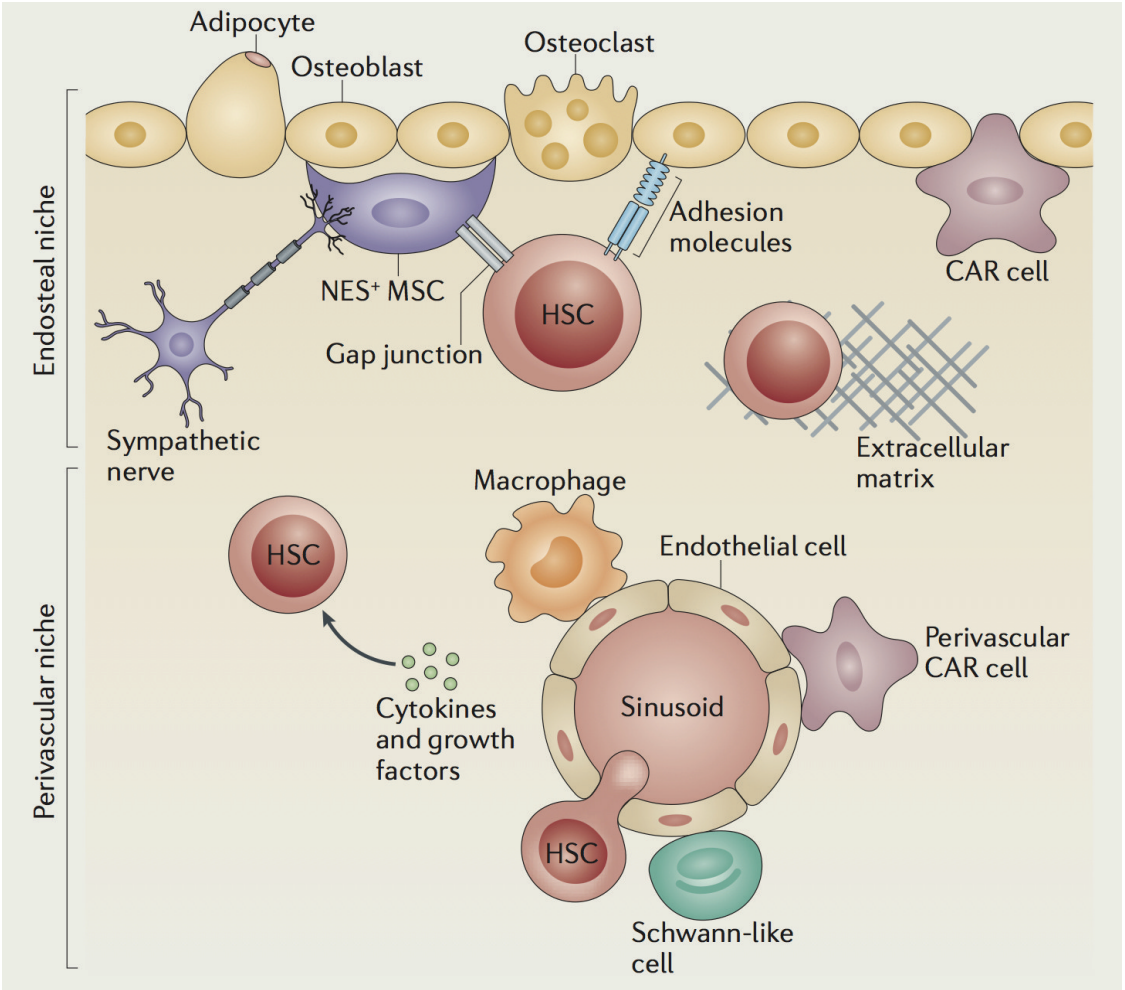

Figure 2. The HSC Niche.(61) (Adapted with permission from Nature Publishing Group).
HSCs.(67) Regulatory signals within the niche emanate from surrounding cells in the form of bound or secreted molecules and also from physical cues such as oxygen tension, shear stress, contractile forces and temperature. $(65,68,69)$ During homeostasis, the majority of HSCs are quiescent but can become activated to proliferate and differentiate in response to infectious stress such as interferon- mediated signaling.
$(71-73)$

MSC are adult tissue committed stem cells found in the bone marrow and other tissues that are capable of mobilizing, proliferating, and committing to terminally differentiated cell types such osteoblasts, adipocytes, chondrocytes, tenocytes, and myocytes. $(75,76)$ It has also been noted that MSC may be capable of differentiating

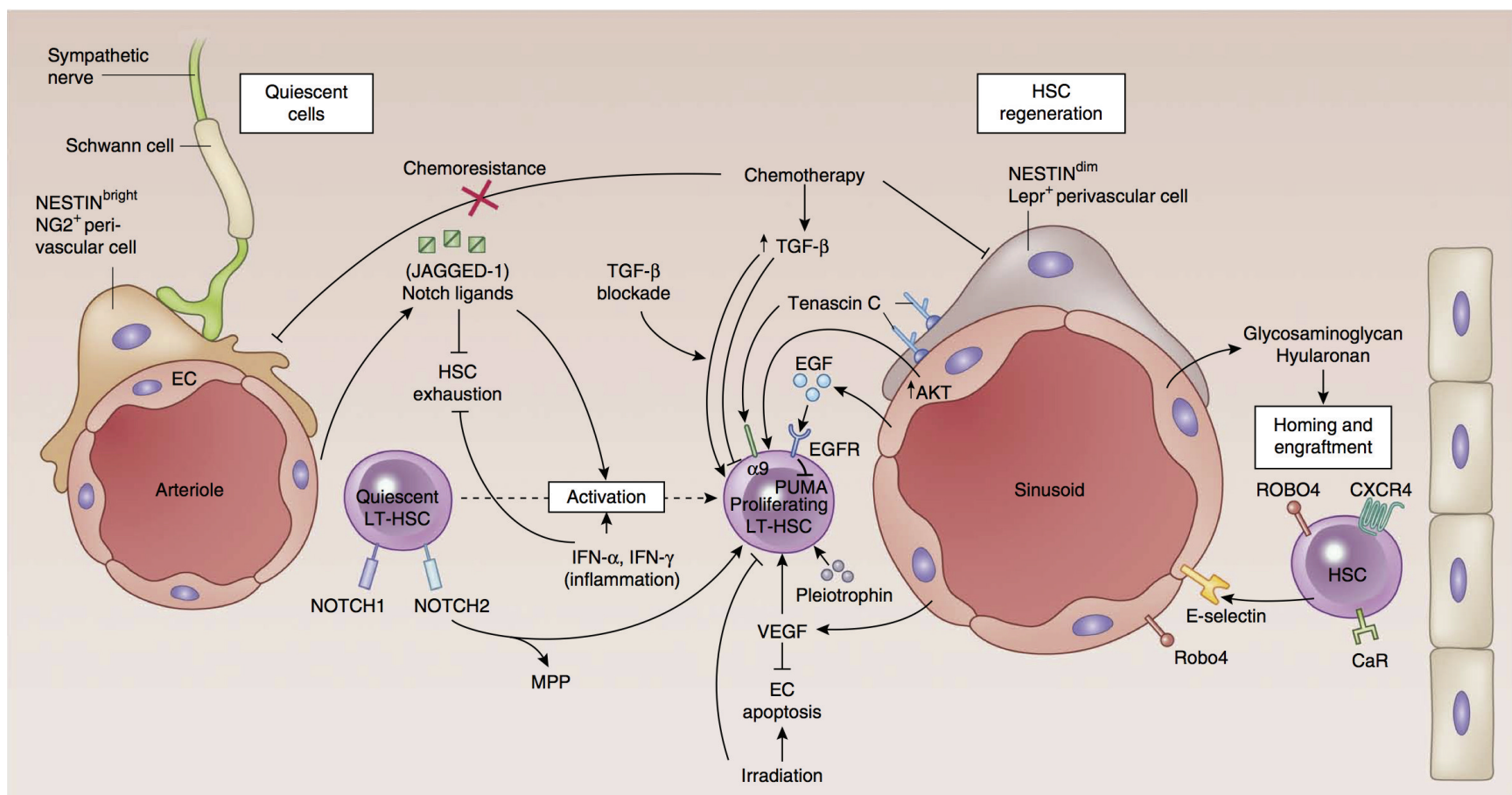

Figure 3. The vascular niche's effect on regeneration.(74) (Adapted with permission from Nature Publishing Group). 
into other lineages such as neurons, glial cells, and hepatocytes.(77-79) The ability to generate these two cells types coupled to their anatomical location in the bone marrow indicates that MSC may be a key component of the niche that supports and controls the activity of HSCs.

Published evidence suggests that MSC functionality changes with donor age; primarily this involves alterations in their differentiation capacity namely reduced myogenic and osteogenic differentiation coupled to enhanced adipogenesis. These alterations in differentiation ability seem to depend on anatomical location; for example, the effectiveness of the hematopoietic niche may be diminished by reducing MSC differentiation to osteoblasts in favor of adipocytes.(18)

Stem cell aging underlies the aging of tissues, especially those with a high cellular turnover. There is growing evidence that the aging of the immune system is initiated at the very top of the hematopoietic hierarchy and that the aging of HSC directly contributes to changes in the immune system, referred to as immunosenescence. (60) Aging is known to affect directly stem cells (intrinsic factors) and to provoke changes in their microenvironment (extrinsic factors). In either case, the modifications in the stem cells and their niches result in impaired niche activity.

Aging negatively affects several aspects of HSC function through both intrinsic and microenvironment- mediated mechanisms, leading to decreased self renewal, loss of cell polarity, impaired homing ability and a biased differentiation into the myeloid lineage. Intrinsic effects include increased ROS levels leading to DNA damage and replicative senescence. Additional consequences of intrinsic changes include stem cell exhaustion and decreased hematopoietic cell repopulation capacity, as well as reduced survival rates. Observed extrinsic changes include decreased adhesion to bone marrow stromal cells and increased adipocyte numbers with aging, leading to reduced hematopoietic activity.(74) The ability of organs to adapt to cellular dysfunction, physical damage or physiological changes relies heavily on the properties of stem cells and niches. Both homed stem cell populations and their support microenvironments provide tissues with the plasticity necessary for their adaptation to local or systemic variations, a characteristic that allows organs respond to nutritional stress or aging, among other challenges.

\section{Cellular Senescence and Aging}

Aging is the largest risk factor for most chronic diseases, which account for the majority of morbidity and health care expenditures in developed nations. New findings suggest that aging is a modifiable risk factor, and it may be feasible to delay age-related diseases as a group by modulating

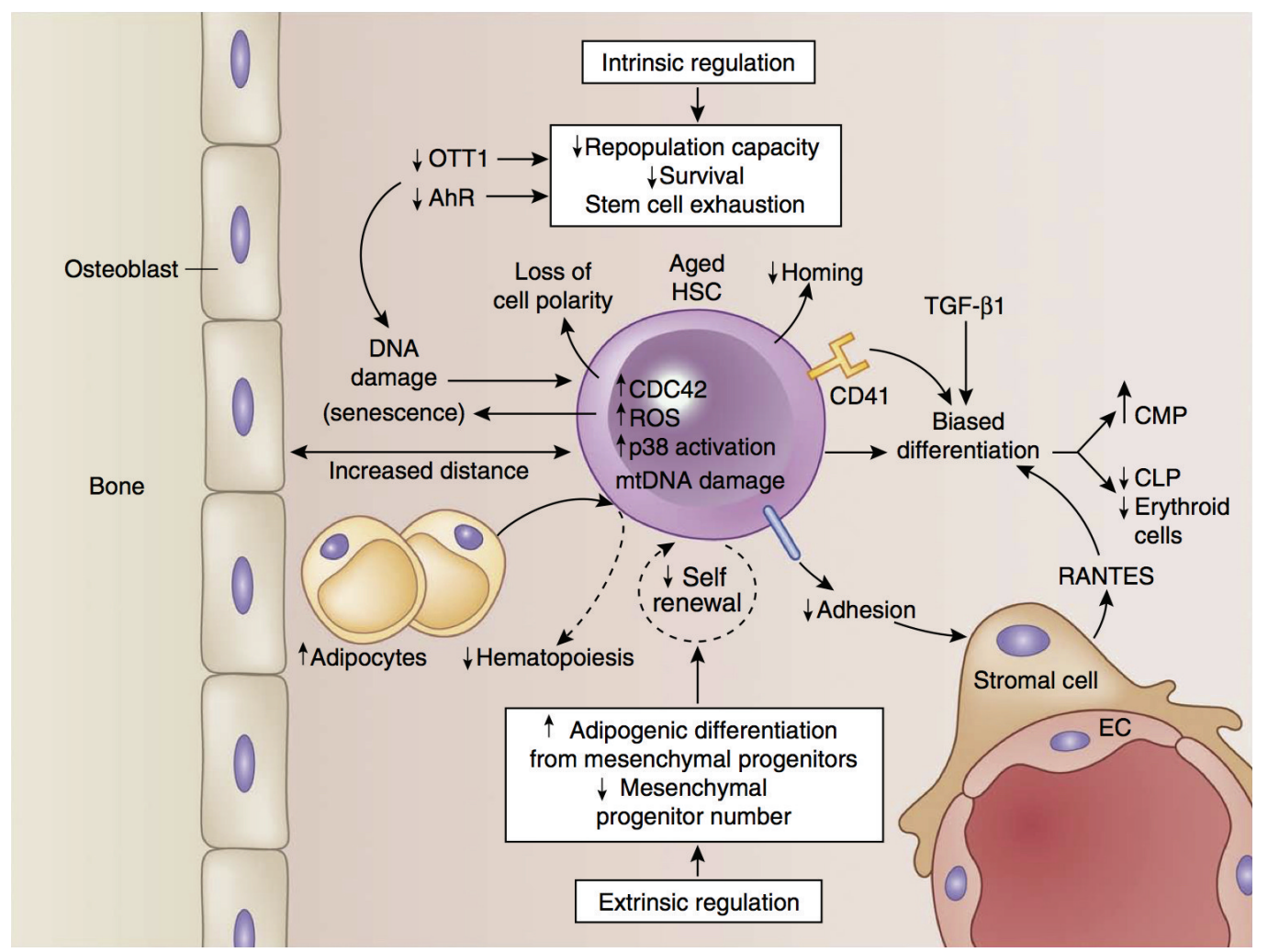

Figure 4. The effects of aging on HSC behavior.(74) (Adapted with permission from Nature Publishing Group). 
fundamental aging mechanisms. One such mechanism is cellular senescence, which can cause chronic inflammation through the senescence-associated secretory phenotype (SASP).(80) Cellular senescence refers to the essentially irreversible growth arrest that occurs when cells experience potentially oncogenic insults.(81-86) There is now strong evidence that cellular senescence is a potent anticancer mechanism.(87-90)

Senescence-causing inducers include repeated cell division and strong mitogenic signals, telomere shortening, DNA damage and mutations, protein aggregation, and increased ROS.(91-96) These insults activate the p53 and p16INK4a tumor suppressor pathways and potentially other pathways that initiate a senescence response. Once initiated, senescence takes days to weeks to become fully established and irreversible. The process is reinforced by an intracellular signaling loop including ROS linked to DNA damage response (DDR), nuclear factor kappa-light-chain-enhancer of activated $\mathrm{B}$ cells $(\mathrm{NF}-\mathrm{\kappa B})$, and transforming growth factor- $\beta$ (TGF $\beta$ ), as well as an Interleukin (IL)- $1 \alpha$, IL-6, and Cytidine-Cytidine-Adenosine-Adenosine-Thymidine (CCAAT) enhancer binding protein- $\beta$ (C/EBP- $\beta$ ) loop. (95,97-100) Senescent cells reorganize chromatin, resulting in heterochromatin formation, extensive gene expression changes, increased cell size and protein content, and changes in cell and organelle shape.(101-103) Senescent cells are metabolically active, relatively resistant to apoptosis, and appear to be removed by the immune system.(104-106) Senescence is effectively a cell fate that, like replication, differentiation, or apoptosis, can occur at any point in life.

Chronic inflammation may also derive in part from senescent cells: senescent cells secrete proinflammatory cytokines, chemokines, and proteases, termed the SASP. $(106,107)$ The SASP is primarily a DDR.(108) The SASP, through the inflammatory, growth-promoting, and remodeling factors that it produces, can potentially explain how senescent cells alter tissue microenvironments, attract immune cells, and, ironically, induce malignant phenotypes in nearby cells. Proteins that are associated with the SASP, such as tumor necrosis factor (TNF)- $\alpha$, IL-6, matrix metalloproteinases (MMP), monocyte chemoattractant protein-1 (MCP-1), and insulin-like growth factorbinding protein (IGFBP), increase in multiple tissues with chronological aging (100), and occur in conjunction with sterile inflammation. Furthermore, expression of the SASP components, IL-6, IGFBP-2, and plasminogen activator inhibitor-1, is much higher in p16INK4a-positive senescent cells isolated directly from fat tissue of older progeroid mice compared with non-senescent cells from the same tissue. (109) This finding suggests that the SASP is the main driver of age-related inflammation, at least in fat tissue under certain conditions. Thus, selective elimination of senescent cells or their effects might be a means to reduce age-related sterile chronic inflammation, enhance health span, and interrupt the link between aging and chronic disease.(80)

Senescence is to initiate a sequence of processes that eliminate damaged cells and culminate in tissue regeneration (we refer to this sequence of events as senescence-clearanceregeneration). However, this beneficial process can be corrupted, particularly in aged tissues, by a combination of factors: on the one hand, clearance of senescent cells by the immune system may become impaired leading to a net accumulation of senescent cells, which may further aggravate tissue dysfunction through the SASP $(100,110)$; on the other hand, senescence may not only affect differentiated cells but also stem and progenitor cells, thus limiting the regenerative capacity of tissues. The combination of inefficient clearance, excessive SASP and ineffective regeneration may explain the accumulation of senescence during aging and its active contribution to some aging phenotypes.(111)

In order to offset the detrimental effects of aging, stem cells have evolved reinforcing mechanisms to ensure the maintenance of their genomic integrity.(112) When those error-prevention checkpoints fail, tumor suppressor mechanisms such as senescence and apoptosis are activated. (113) Over time, cellular senescence characterized by cell cycle arrest limits the ability of stem cells to replace damaged or dysfunctional cells. $(97,114)$ Therefore, although senescence reduces oncogenic risk, this is at the expense of limiting the replicative capacity of stem cells, delaying tissue repair and ultimately promoting aging.(97,114-116)

Therefore, the elimination of senescent cells is a promising strategy to reduce chronic systemic inflammation and to rejuvenate tissues. $(117,118)$ In summary, senescence is a response that is primarily designed to eliminate damaged cells; however, with advancing age, the full sequence of senescence-clearance-regeneration is not entirely accomplished and senescence may become part of the problem rather than its solution. As a result of this duality, senescence is considered an example of 'antagonistic pleiotropy' (1) and it has been categorized as an 'antagonistic' hallmark of aging (119).

\section{Caloric Restriction (CR), SIRT and Aging}

The phenomenon of aging is an intrinsic feature of life. Accordingly, the possibility to manipulate it has fascinated humans likely since time immemorial. Recent evidence is shaping a picture where low caloric regimes and exercise may improve healthy senescence, and several pharmacological 
strategies have been suggested to counteract aging.(120) There are only a few proposed aging interventions that have met such stringent criteria: fasting regimens, CR, exercise, and the use of low-molecular-weight compounds, including spermidine, metformin, resveratrol, and rapamycin. From a molecular point of view, these interventions may act through epigenetic mechanisms (histone acetylation/methylation), the insulin/target of rapamycin (TOR) pathway, the Rat Sarcoma (Ras) signaling pathway, mitochondrial function, proteostasis, autophagy, and stress resistance.(120)

The reduction in the intake of calories without malnutrition is defined as CR. Such reduction ideally corresponds to a decrease of approximately $30 \%$ of calories per day, at least in mice. In humans, there is some indication that a CR of around 15\% may be most favorable against mortality during aging.(121) CR reduces the release of growth factors like growth hormone, insulin, and insulinlike growth factor (IGF)-1, which have been shown to accelerate aging and increase mortality in many organisms. (122) CR-mediated longevity in eukaryotes seems to be governed by a set of conserved nutrient signaling pathways. (122) Among them are the insulin and the TOR/S6K pathways, whose inhibition upon CR eventually confers stress resistance and promotes survival during aging. Stressrelated transcription factors represent the common effectors in yeast, flies, worms, and mammals.(122) Moreover, the histone deacetylase single information regulator (Sir)2 (the founding member of the SIRT family) has been linked to CR-mediated antiaging effects in yeast mother cells, flies, and mammals.(123) SIRT-mediated control of protein acetylation might not be restricted to chromatin packaging and transcriptional modulation, as the mitochondrial SIRT, SIRT3 has been proposed to play an important role in the prevention of age-related diseases, possibly through modulation of the mitochondrial acetylproteome.(124)

The original proposal was based on the findings that SIRT were nicotinamide adenine dinucleotide (NAD+)dependent protein deacetylases and known to counter aging in yeast. Now, years later, a large volume of data, particularly from mammals, begins to illustrate an elaborate set of physiological adaptations to caloric intake mediated by SIRT. Studies that connect SIRT activation with prevention of aging and diseases of aging in mouse models are many. It is also clear that other nutrient sensors, such as adenosine monophosphate-activated protein kinase (AMPK) (125), mammalian TOR (mTOR) (126), and forkhead box O (FOXO) (127) are very important in linking diet, metabolism, and aging. Indeed, numerous connections among all of these pathways are evident in the literature.
(128) Perhaps the most direct indication that SIRT play an important role in the physiological adaptation to $\mathrm{CR}$ comes from a more detailed analysis of their substrates and physiological effects. Two hallmarks of CR are metabolic reprogramming to oxidative metabolism (to gain the most possible energy from fuel sources) and resistance to stress, particularly oxidative stress.(128)

SIRT1 plays a central role in inducing mitochondrial biogenesis, stress tolerance, and fat metabolism. This SIRT deacetylates peroxisome proliferator-activated receptor gamma coactivator 1-alpha (PGC-1 $\alpha)(129,130)$, FOXO1 (131,132), and peroxisome proliferator-activated receptors (PPAR) $\alpha$ (133). In this regard, SIRT1 activity is tightly linked to AMPK $(134,135)$, since AMPK drives expression of the NAD + synthetic enzyme nicotinamide phosphoribosyltransferase (NAMPT) $(136,137)$, and SIRT1 deacetylates and activates the AMPK activator kinase liver kinase B1 (LKB1) $(138,139)$. At the same time, SIRT1 turns down glycolytic metabolism by deacetylating glycolytic enzymes (140) and one of their key transcriptional inducers, hypoxia-inducible factor (HIF)-1 $\alpha$ (141). These SIRT functions may help explain the global anti-inflammatory effect of CR, which may be an important mechanism by which this diet slows aging. Indeed, NF- $\kappa \mathrm{B}$ activation has been linked to aging (142), a topic explored further below.

SIRT1 was first linked to circadian control via the peripheral and autonomous clock in the liver. In this tissue, SIRT1 deacetylates circadian clock proteins Brain and Muscle ARNT-Like (BMAL)1 and period circadian clock 2 (PER2) $(143,144)$ to influence their function. In the liver, the clock also regulates NAMPT, rendering SIRT activity circadian and providing a link between the clock and metabolism $(145,146)$. Interestingly, SIRT1 has been shown recently to also control central circadian function in the brain by amplifying expression of BMAL1.(147) Importantly, SIRT1 levels decline in the suprachiasmatic nucleus ( $\mathrm{SCN}$ ) of aged mice compared with young controls. This decline is concomitant with the reduction of many of the components of the circadian clock, presumably triggering the degradation of central circadian function with aging.(148) Remarkably, overexpressing SIRT1 in the brain blunts the effects of aging on circadian function, and deletion of SIRT1 compromises function in young animals. SIRT1 deacetylates PGC-1 $\alpha$ in neurons to increase activation of BMAL transcription. Thus, a loop of SIRT1, PGC-1 $\alpha$, and NAMPT amplifies the expression of circadian clock proteins and assures proper central circadian function in the SCN.(147)

Resveratrol is a polyphenol that is found in grapes 
and in red wine. Its potential to promote lifespan was first identified in yeast (149), and it has since gained fame because it was suggested to be responsible for the so-called French paradox. In monkeys fed a diet high in sugar and fat, resveratrol supplementation attenuated peripheral inflammation in adipose tissue (150), maintained pancreatic homeostasis by preventing $\beta$ cell dedifferentiation (151), and improved vascular function, particularly pulse wave velocity (152). Resveratrol treatment prolongs the lifespan of mice fed a high-fat diet or fed every other day (153), but not of mice on regular chow. This polyphenolic compound prolongs the life of flies (154), worms (155), and the replicative lifespan of yeast (149).

The mechanisms behind these effects may rely on the fact that resveratrol mimics some of the metabolic actions of $\mathrm{CR}$, as a series of studies on humans have suggested. (156) Resveratrol interacts with many stress-related targets in the cell, including the mammalian NAD+-dependent deacetylase SIRT1 $(155,157)$, although the resveratrolSIRT1 interaction may be indirect (158). SIRT1 is a member of a family of proteins (SIRT) that have been linked to longevity in yeast, flies, and worms. $(123,159,160)$

The aging-associated reorganization of chromatin's structure supports the idea that chromatin-remodeling factors play an important role in the aging process. Histonemodifying enzymes are also important contributors in the aging process. $(10,11)$ It is also well known that SIRT, NAD+-dependent histone deacetylases, are important players in the aging process. Therefore, due to its pleiotropic effects, SIRT1 could be involved in modulating aging at multiple levels, including: gene transcription; cell cycle; signal transduction; stress response; chromatin structure; DNA repair, and genomic integrity.

The aging-associated changes in the nuclear architecture, chromatin structure, altered expression and activity of chromatin remodeling factors, and change in pattern of epigenetic marks (DNA methylation and histone modification) affect all cells in the adult body including the population of stem cells responsible for proper tissue rejuvenation. Therefore, the elucidation of these precise mechanisms will help to develop more efficient anti-aging strategies as well as facilitate a better understanding of agerelated risks for cancer genesis.(12)

\section{Rejuvenate Our Aging Stem Cells}

Aging tissues experience a progressive decline in homeostatic and regenerative capacities, which has been attributed to degenerative changes in tissue-specific stem cells, stem cell niches and systemic cues that regulate stem cell activity. ASCs, or resident stem cells, are undifferentiated cells found in adults throughout life.(162) These cells are characterized by two developmental capacities: selfrenewal, the ability to give rise to daughter stem cells, and multipotency, the capacity to differentiate into various cell types of a particular organ. These properties provide stem cells the ability to sustain their population during life, and to maintain tissue remodeling and repair (15), facilitating the rationale for using ASC in regenerative medicine (163).

Stem cell function declines with age and this occurs at multiple levels, including self-renewal and differentiation potential, leading to reduced regenerative capacity of all tissues and organs. Moreover, age-related alterations in stem cells contribute to distinct pathophysiological characteristics depending on the tissue of origin and function. Thus, given the perspectives of ASC in regenerative therapy, understanding these processes and their role in age-related diseases is vital.(19)

An interesting addition to the data supporting a significant epigenetic contribution to stem cell aging comes from the apparent ability of some ASC to reacquire a youthful ability to regenerate their tissue compartments through changes in their microenvironment. Repair/ regeneration of the skeletal muscles is most probably performed by satellite cells, a stem cell population residing beneath the basal lamina of the myofibers.(164) Muscle damage results in an inflammatory response causing the normally quiescent satellite cells to proliferate and migrate to the site of damage. The age-related decline in muscle mass and strength known as sarcopenia is thought to result, at least in part from compromised satellite cell function. A more interesting demonstration of functional rejuvenation comes from heterochronic parabiosis experiments in which the circulatory system of old and young animals was surgically joined.(13,165) Satellite cells isolated from old humans and mice show similar functional defects in their notch and TGF $\beta$ signaling pathways but factors present in the peripheral blood of young mice are able to restore these to a state of activity similar to those of young mouse satellite cells. These data imply that the age-related decline in satellite cell function may not arise because of irreversible errors such as the accumulation of DNA damage but may be due to reversible epigenetic changes.(18)

An alternative explanation for the effects of microenvironment on stem cell function could be the SASP $(80,166)$ in which the progressive accumulation of senescent cells within a tissue alters the microenvironment by secreting various factors such as IL-6. The regulation of senescent 
cell accumulation and impact upon the progression of an aged phenotype are not clear but published data suggest that that removal of senescent cells can prevent or delay tissue dysfunction.(109)

The rejuvenating effects of a young systemic environment do not appear to be restricted to the skeletal muscles. Neurogenesis is subject to an age-related decline in the murine central nervous system (CNS) $(31,167,168)$ but this seems to be partially rescued in heterochronic parabionts (51). Again, the decline in neurogenesis seems to be reversible by other factors since deletion of the Wnt antagonist Dickkopf1 (DKK1) (whose expression increases during normal aging of the CNS) (169) can increase the self renewal of neural stem cells and contribute to improved spatial learning and memory in older mice, while increases in the level of the cytokine $\mathrm{C}-\mathrm{C}$ motif chemokine 11 (CCL11) in the blood of young mice are sufficient to reduce neurogenesis and CNS function. These observations appear to support an epigenetic contribution to aging but at present there are insufficient data from which to draw clearer conclusions. By analogy to the attainment of a pluripotent state by epigenetic reprogramming of a differentiated cell, is cellular rejuvenation by heterochronic parabiosis, NF$\kappa \mathrm{B}$ inhibition, or inhibition of mTOR signaling (Figure 5) a form of epigenetic reprogramming from an aged state to a youthful state? If so, then these would be examples of an uncoupling of the differentiation program from the aging clock, with cells in each case manifesting an apparent rewinding of the aging clock without loss of differentiation.

Clearly, any therapeutic goal of cell or tissue rejuvenation would aim to restore a "young adult" state from an elderly state, not rewinding the aging clock back to embryonic or even postnatal developmental stages when growth and morphogenesis are paramount and the systemic milieu is very different from that in the adult. The challenge would be to reset the aging clock back to the appropriate adult stage. Another challenge is the coordination of reprogramming among different cell types in multicellular organisms. As such, the most feasible near-term applications of any type of rejuvenating intervention for therapeutic purposes would be those that could be administered in a temporally and spatially controlled manner (e.g., to a specific site of wound repair or tissue injury for a limited time).(3)

Aging is characterized by a progressive decline in metabolic homeostasis. A comprehensive insight into cellular processes that respond to metabolic imbalances will be useful in identifying new avenues for therapeutic intervention against age-related diseases. Mitochondria

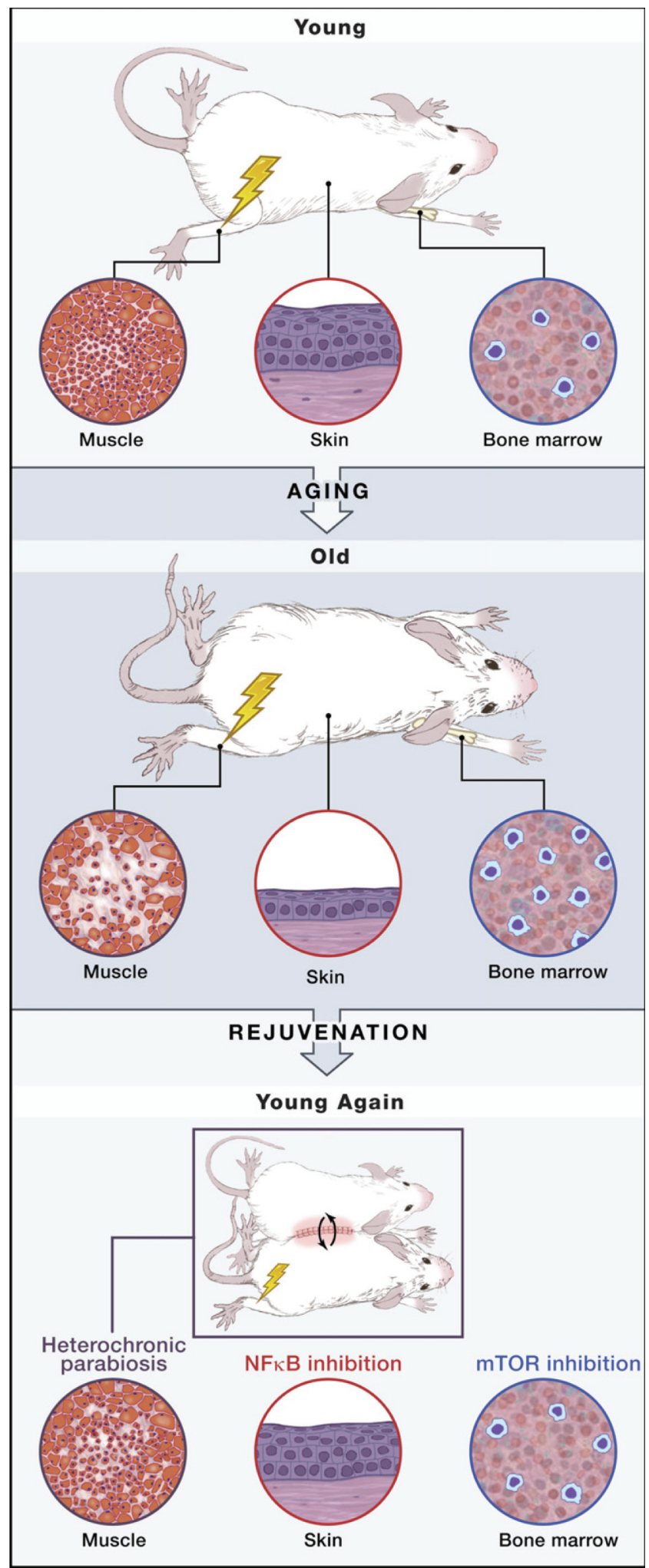

Figure 5. Rejuvenation without Dedifferentiation.(6) (Adapted with permission from Elsevier Inc)

play a central role in such processes, as they are the hubs of metabolic activity in eukaryotic cells and significantly influence the intracellular energy balance and redox milieu. 
The function of mitochondria as sensors of metabolic imbalances and as mediators of specific cellular stress responses that can impact longevity has recently garnered increased attention. Mitochondrial dysfunction has long been implicated in aging, primarily as a source of metabolic stress and of reactive oxygen species. $(170,171)$

CR enhanced endogenous muscle repair and CR initiated in either donor or recipient animals improved the contribution of donor cells to regenerating muscle after transplant. These studies indicate that metabolic factors play a critical role in regulating stem cell function and that this regulation can influence the efficacy of recovery from injury and the engraftment of transplanted cells.(49) SIRT3 is dispensable for HSC maintenance and tissue homeostasis at a young age under homeostatic conditions but is essential under stress or at an old age. Importantly, SIRT3 is suppressed with aging, and SIRT3 upregulation in aged HSCs improves their regenerative capacity. This study illuminates the plasticity of mitochondrial homeostasis controlling stem cell and tissue maintenance during the aging process and shows that aging-associated degeneration can be reversed by a SIRT.(8)

Now it is well accepted that SIRT play important roles in a broad spectrum of biological processes, although questions still remain. SIRT function to slow aging and various disorders associated with aging, including metabolic diseases, cancer, and neurodegenerative conditions. SIRT respond to the energy availability provided by the diet to determine the acetylation status of histones, key transcription factors, and metabolic enzymes. This coordinated response helps deliver the benefits of CR on health and physiology. Indeed, Resveratrol have been shown to target SIRT1 directly $(172,173)$, and present a promising strategy to ameliorate age-related diseases. Novel drugs for other SIRTs may also become available and offer additional benefits. And finally, NAD+ supplementation in combination with SIRT-activating compound (STAC) may offer a synergetic strategy to promote healthy aging.(6)

Understanding the molecular processes controlling stem cell survival, self-renewal, quiescence, proliferative expansion and commitment to specific differentiated cell lineages is crucial to determining the drivers and effectors of age-associated stem cell dysfunction. Furthermore, such knowledge will be essential to inform development of therapeutic interventions that can slow, and perhaps reverse, age-related degenerative changes to enhance repair processes and maintain healthy function in aging tissues. In the context of conserved cellular processes, accumulation of toxic metabolites, DNA damage, proteostasis, mitochondrial dysfunction, proliferative exhaustion, extracellular signaling and epigenetic remodeling that clearly affect the activity of both stem cells and non-stem cells with age and may be linked to mechanisms that determine organismal lifespan and healthspan (Figure 6).(161)

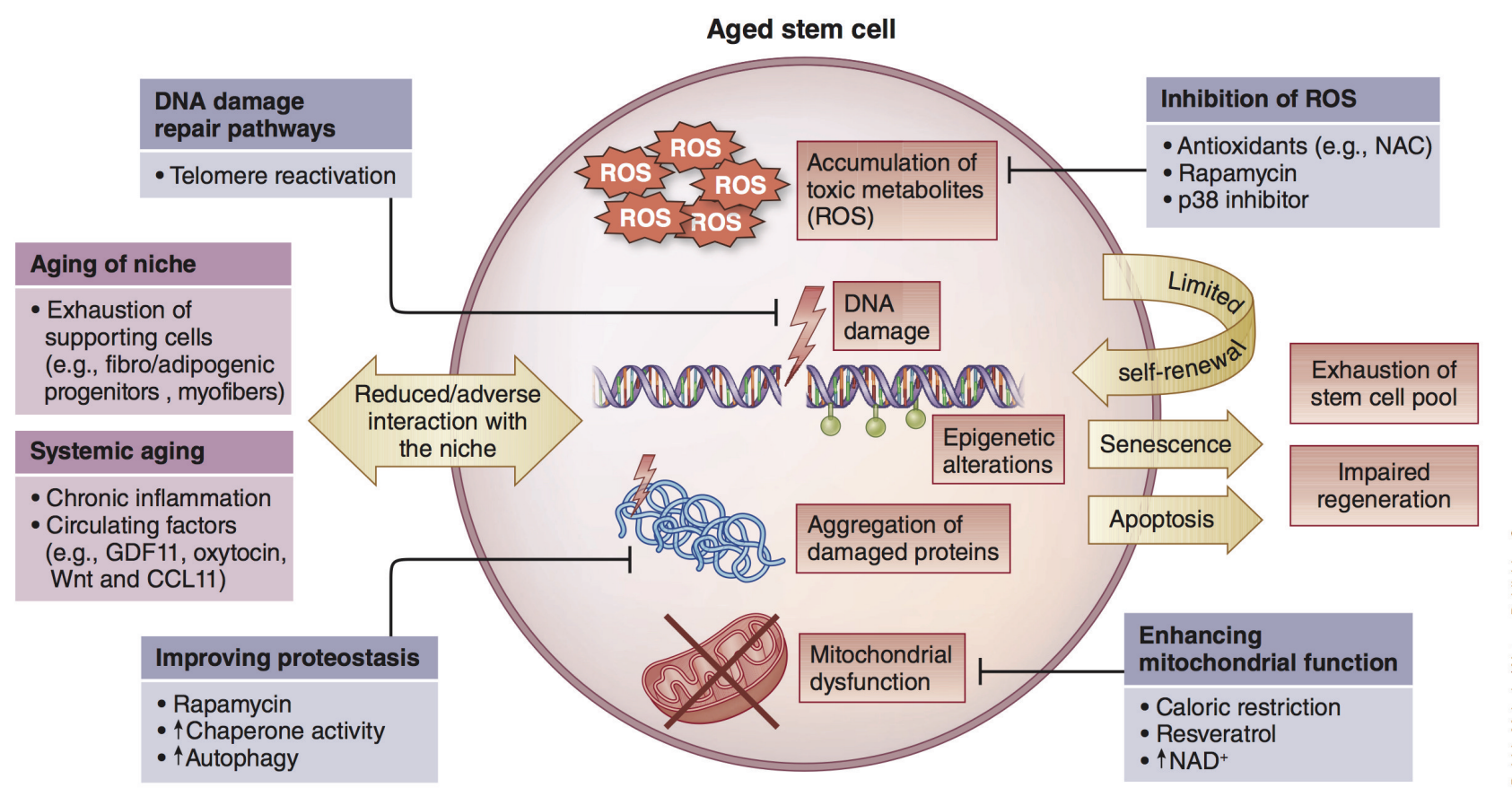

Figure 6. Common pathways contributing to stem cell loss and dysfunction in the aging process. Common aging phenotypes within the stem cell are shown in red, in the niche in pink, and the strategies by which to target and hopefully reverse these mechanisms in purple. (161) (Adapted with permission from Nature Publishing Group) 


\section{Conclusion}

Stem cell aging is affected by many different cell-intrinsic and cell-extrinsic pathways, which often show crosstalk in the determination of stem cell function. This interdependence makes it difficult to place particular weight on any one pathway with respect to aging mechanisms; however, certain signals do appear more broadly involved than others, at least given available data, and this could imply that they are more important regulators of aging stem cells. Likewise, mitochondrial function, largely regulated by SIRT, not only affects stem cell functions directly but also causes secondary effects on ROS and nutrient-sensing activities, which further modulate stem cell phenotypes.

Nonetheless, observations of the reversibility of stem cell aging have generated excitement about the development of 'rejuvenating' interventions that could extend the healthy years of life. Improving the health span of elders takes on increasing urgency as human lifespans continue to increase, and even small gains in health span could dramatically lessen the impact of an aging population on the health care system and economy. Although clearly there is much still to be discovered about stem cell function, aging and the pathways to therapy, what we know so far clearly encourages further studies. By continuing to clarify the fundamental mechanisms by which stem cells age, ongoing research will develop interventions that someday may change the way we age.

\section{References}

1. Lopez-Otin C, Blasco MA, Partridge L, Serrano M, Kroemer G. The hallmarks of aging. Cell. 2013; 153: 1194-217.

2. Della-Morte D, Ricordi C, Rundek T. The fountain of youth: role of sirtuins in aging and regenerative medicine. Regen Med. 2013; 8: 681-3.

3. Rando TA, Chang HY. Aging, rejuvenation, and epigenetic reprogramming: resetting the aging clock. Cell. 2012; 148: 46-57.

4. Haigis MC, Yankner BA. The aging stress response. Mol Cell. 2010; 40: 333-44.

5. Satoh A, Brace CS, Rensing N, Cliften P, Wozniak DF, Herzog ED, et al. Sirt1 extends life span and delays aging in mice through the regulation of Nk2 homeobox 1 in the DMH and LH. Cell Metab. 2013; 18: 416-30.

6. Chang HC, Guarente L. SIRT1 and other sirtuins in metabolism Trends Endocrinol Metab. 2014; 25: 138-45.

7. Guarente L. Aging research-where do we stand and where are we going? Cell. 2014; 159: 15-9.

8. Brown K, Xie S, Qiu X, Mohrin M, Shin J, Liu Y, et al. SIRT3 reverses aging-associated degeneration. Cell Rep. 2013; 3: 319-27.

9. Bergmann O, Bhardwaj RD, Bernard S, Zdunek S, Barnabé-Heider
F, Walsh S, et al. Evidence for cardiomocyte renewal in humans. Science. 2009; 324: 98-102.

10. Oberdoerffer P, Sinclair DA. The role of nuclear architecture in genomic instability and aging. Nat Rev Mol Cell Biol. 2007; 8: 692 702 .

11. Fraga MF, Esteller M. Epigenetics and aging: the targets and the marks. Trends Genet. 2007; 23: 413-8.

12. Shin DM, Kucia M, Ratajczak MZ. Nuclear and chromatin reorganization during cell senescence and aging - a mini-review. Gerontology. 2011; 57: 76-84.

13. Conboy IM, Rando TA. Aging, stem cells and tissue regeneration: lessons form muscle. Cell Cycle. 2005; 4: 407-10.

14. Sharpless NE, DePinho RA. Telomeres, stem cells, senescence, and cancer. J Clin Invest. 2004; 113: 160-8.

15. Bryder D, Rossi DJ, Weissman IL. Hematopoietic stem cells: the paradigmatic tissue specific stem cell. Am J Pathol. 2006; 169: 33846.

16. Morrison SJ, Kimble J. Asymmetric and symmetric stem-cell divisions in development and cancer. Nature. 2006; 441: 1068-74.

17. Meiliana A, Wijaya A. The stem cell hypothesis of aging. Indones Biomed J. 2010; 2: 26-44.

18. Armstrong L, Al-Aama J, Stojkovic M, Lako M. Concise review: the epigenetic contribution to stem cell ageing: can we rejuvenate our older cells? Stem Cells. 2014; 32: 2291-8.

19. Raveh-Amit H, Berzsenyi S, Vas V, Ye D, Dinnyes A. Tissue resident stem cells: till death do us part. Biogerontology. 2013; 14: 573-90.

20. Carlson ME, Conboy IM. Loss of stem cell regenerative capacity within aged niches. Aging Cell. 2007; 6: 371-82.

21. Sager R. Senescence as a mode of tumor suppression. Environ Health Perspect. 1991; 93: 59-62.

22. Weinstein BS, Ciszek D. The reserve-capacity hypothesis: evolutionary origins and modern implications of the trade-off between tumor-suppression and tissue-repair. Exp Gerontol. 2002; 37: 615-27.

23. Pearson BJ, Sanchez Alvarado A. Regeneration, stem cells, and the evolution of tumor suppression. Cold Spring Harb Symp Quant Biol. 2008; 73: 565-72.

24. Nizetic D, Groet J. Tumorigenesis in Down's syndrome: big lessons from a small chromosome. Nat Rev Cancer. 2012; 12: 721-32.

25. Kuranda K, Vargaftig J, de la Rochere P, Dosquet C, Charron D, Bardin F, et al. Age-related changes in human hematopoietic stem/ progenitor cells. Aging Cell. 2011; 10: 542-6.

26. Muller-Sieburg C, Sieburg HB. Stem cell aging: survival of the laziest? Cell Cycle. 2008; 7: 3798-804

27. Warren LA, Rossi DJ. Stem cells and aging in the hematopoietic system. Mech Ageing Dev. 2009; 130: 46-53.

28. Chambers SM, Shaw CA, Gatza C, Fisk CJ, Donehower LA, Goodell MA. Aging hematopoietic stem cells decline in function and exhibit epigenetic dysregulation. PLoS Biol. 2007; 5: e201.

29. Janzen V, Forkert R, Fleming HE, Saito Y, Waring MT, Dombkowski $\mathrm{DM}$, et al. Stem-cell ageing modified by the cyclin-dependent kinase inhibitor p16INK4a. Nature. 2006; 443: 421-6.

30. Krishnamurthy J, Ramsey MR, Ligon KL, Torrice C, Koh A, BonnerWeir S, et al. p16INK4a induces an age-dependent decline in islet regenerative potential. Nature. 2006; 443: 453-7.

31. Molofsky AV, Slutsky SG, Joseph NM, He S, Pardal R, Krishnamurthy $\mathrm{J}$, et al. Increasing p16INK4a expression decreases forebrain progenitors and neurogenesis during ageing. Nature. 2006; 443: 448-52.

32. Nishino J, Kim I, Chada K, Morrison SJ. Hmga2 promotes neural stem cell self-renewal in young but not old mice by reducing 
p16Ink4a and p19Arf Expression. Cell. 2008; 135: 227-39.

33. Toledano H, D'Alterio C, Czech B, Levine E, Jones DL. The let-7Imp axis regulates ageing of the Drosophila testis stem-cell niche. Nature. 2012; 485: 605-10.

34. He S, Nakada D, Morrison SJ. Mechanisms of stem cell self-renewal. Annu Rev Cell Dev Biol. 2009; 25: 377-406.

35. Sato T, Vries RG, Snippert HJ, van de Wetering M, Barker N, Stange $\mathrm{DE}$, et al. Single Lgr5 stem cells build crypt-villus structures in vitro without a mesenchymal niche. Nature. 2009; 459: 262-5.

36. Munoz J, Stange DE, Schepers AG, van de Wetering M, Koo BK, Itzkovitz S, et al. The Lgr5 intestinal stem cell signature: robust expression of proposed quiescent ' +4 ' cell markers. EMBO J. 2012; 31: 3079-91.

37. Powell AE, Wang Y, Li Y, Poulin EJ, Means AL, Washington MK, et al. The pan-ErbB negative regulator Lrig1 is an intestinal stem cell marker that functions as a tumor suppressor. Cell. 2012; 149: 14658.

38. Reya T, Morrison SJ, Clarke MF, Weissman IL. Stem cells, cancer, and cancer stem cells. Nature. 2001; 414: 105-11.

39. Liang R, Ghaffari S. Stem cells, redox signaling, and stem cell aging. Antioxid Redox Signal. 2014; 20: 1902-16.

40. Ahlqvist KJ, Hämäläinen RH, Yatsuga S, Uutela M, Terzioglu M, Götz A, et al. Somatic progenitor cell vulnerability to mitochondrial DNA mutagenesis underlies progeroid phenotypes in Polg mutator mice. Cell Metab. 2012; 15: 100-9.

41. Bratic A, Larsson NG. The role of mitochondria in aging. J Clin Invest. 2013; 123: 951-7.

42. Dillin A, Hsu AL, Arantes-Oliveira N, Lehrer-Graiwer J, Hsin $\mathrm{H}$, Fraser AG, et al. Rates of behavior and aging specified by mitochondrial function during development. Science. 2002; 298, 2398-401

43. Choudhury AR, Ju Z, Djojosubroto MW, Schienke A, Leche, A, Schaet-zlein $\mathrm{S}$, et al. Cdknla deletion improves stem cell function and lifespan of mice with dysfunctional telomeres without accelerating cancer formation. Nat Genet. 2007; 39: 99-105.

44. Rossi DJ, Bryder D, Seita J, Nussenzweig A, Hoeijmakers J, Weissman IL. Deficiencies in DNA damage repair limit the function of haematopoietic stem cells with age. Nature. 2007; 447: 725-9.

45. Sahin E, Depinho RA. Linking functional decline of telomeres, mitochondria and stem cells during ageing. Nature. 2010; 464: 520-

46. Lee J, Duan W, Long JM, Ingram DK, Mattson MP. Dietary restriction increases the number of newly generated neural cells, and induces BDNF expression, in the dentate gyrus of rats. J Mol Neurosci. 2000; 15: 99-108.

47. Chen J, Astle CM, Harrison DE. Hematopoietic senescence is postponed and hematopoietic stem cell function is enhanced by dietary restriction. Exp Hematol. 2003; 31: 1097-103.

48. Mair W, McLeod CJ, Wang L, Jones DL. Dietary restriction enhances germline stem cell maintenance. Aging Cell. 2010; 9: 916-8.

49. Cerletti M, Jang YC, Finley LW, Haigis MC, Wagers AJ. Short-term calorie restriction enhances skeletal muscle stem cell function. Cell Stem Cell. 2012; 10: 515-9.

50. Conboy IM, Conboy MJ, Wagers AJ, Girma ER, Weissman IL, Rando TA. Rejuvenation of aged progenitor cells by exposure to a young systemic environment. Nature. 2005; 433: 760-4

51. Villeda SA, Luo J, Mosher KI, Zou B, Britschgi M, Bieri G, et al. The ageing systemic milieu negatively regulates neurogenesis and cognitive function. Nature. 2011; 477: 90-4.

52. Li L, Clevers H. Coexistence of quiescent and active adult stem cells in mammals. Science. 2010; 327: 542-5.
53. Orford KW, Scadden DT. Deconstructing stem cell self-renewal: genetic insights into cell-cycle regulation. Nature Rev Genet. 2008; 9: 115-28.

54. Cheung TH, Rando TA. Molecular regulation of stem cell quiescence. Nat Rev Mol Cell Biol. 2013; 14: 329-40.

55. Hsu YC, Fuchs E. A family business: stem cell progeny join the niche to regulate homeostasis. Nature Rev Mol Cell Biol. 2012; 13: 10314

56. Florian MC, Geiger H. Concise review: polarity in stem cells, disease, and aging. Stem Cells. 2010; 28: 1623-9.

57. Morrison SJ, Spradling AC. Stem cells and niches: mechanisms that promote stem cell maintenance throughout life. Cell. 2008; 132: 598-611.

58. Aichinger E, Kornet N, Friedrich T, Laux T. Plant stem cell niches. Annu Rev Plant Biol. 2012; 63: 615-36.

59. Schofield R. The relationship between the spleen colony-forming cell and the haemopoietic stem cell. Blood Cells. 1978; 4: 7-25.

60. Lander AD, Kimble J, Clevers H, Fuchs E, Montarras D, Buckingham $\mathrm{M}$, et al. What does the concept of the stem cell niche really mean today? BMC Biol. 2012; 10: 19. doi: 10.1186/1741-7007-10-19.

61. Geiger H, de Haan G, Florian C. The ageing haematopoietic stem cell compartment. Nat Rev Immunol. 2013; 13: 376-89.

62. Lucas D, Scheiermann C, Chow A, Kunisaki Y, Bruns I, Barrick C, et al. Chemotherapy-induced bone marrow nerve injury impairs hematopoietic regeneration. Nat Med. 2013; 19: 695-703.

63. Pietras EM, Lakshminarasimhan R, Techner JM, Fong S, Flach J, Binnewies M, et al. Re-entry into quiescence protects hematopoietic stem cells from the killing effect of chronic exposure to type I interferons. J Exp Med. 2014; 211: 245-62.

64. Lymperi S, Ferraro F, Scadden DT. The HSC niche concept has turned 31. Has our knowledge matured? Ann NY Acad Sci. 2010; 1192: $12-8$.

65. Wang LD, Wagers AJ. Dynamic niches in the origination and differentiation of haematopoietic stem cells. Nat Rev Mol Cell Biol. 2011; 12: 643-55.

66. Warr MR, Pietras EM, Passegue E. Mechanisms controlling hematopoietic stem cell functions during normal hematopoiesis and hematological malignancies. Wiley Interdiscip Rev Syst Biol Med. 2011; 3: 681-701.

67. Morrison SJ, Scadden DT. The bone marrow niche for haematopoietic stem cells. Nature. 2014; 505: 327-34.

68. Adamo L, Naveiras O, Wenzel PL, McKinney-Freeman S, Mack PJ, Gracia-Sancho J, et al. Biomechanical forces promote embryonic haematopoiesis. Nature. 2009; 459: 1131-5.

69. Shin JW, Buxboim A, Spinler KR, Swift J, Christian DA, Hunter CA, et al. Contractile forces sustain and polarize hematopoiesis from stem and progenitor cells. Cell Stem Cell. 2014; 14: 81-93.

70. Passegué E, Wagers AJ, Giuriato S, AndersonWC, Wwissman IL. Global analysis of proliferation and cell cycle gene expression in the regulation of hematopoietic stem and progenitor cell fates. J Exp Med. 2005; 202: 1599-611.

71. Essers MA, Offner S, Blanco-Bose WE, Waibler Z, Kalinke U, Duchosal MA, et al. IFN $\alpha$ activates dormant haematopoietic stem cells in vivo. Nature. 2009; 458: 904-8.

72. Wilson A, Laurenti E, Oser G, van der Wath RC, Blanco-Bose W, Jaworski M, et al. Hematopoietic stem cells reversibly switch from dormancy to self-renewal during homeostasis and repair. Cell. 2008; 135: 1118-29.

73. Baldridge MT, King KY, Boles NC, Weksberg DC, Goodell MA Quiescent haematopoietic stem cells are activated by IFN-gamma in response to chronic infection. Nature. 2010; 465: 793-7. 
74. Mendelson A, Frenette PS. Hematopoietic stem cell niche maintenance during homeostasis and regeneration. Nat Med. 2014; 20: 833-46.

75. Chamberlain G, Fox J, Ashton B, Middleton J. Concise review: mesenchymal stem cells: their phenotype, differentiation capacity, immunological features, and potential for homing. Stem Cells. 2007; 25: 2739-49.

76. Noth U, Rackwitz L, Steinert AF, Tuan RS. Cell delivery therapeutics for musculoskeletal regeneration. Adv Drug Deliv Rev. 2010; 62: 765-83.

77. Chen Y, Shao JZ, Xiang LX, Dong XJ, Zhang GR. Mesenchymal stem cells: a promising candidate in regenerative medicine. Int $\mathrm{J}$ Biochem Cell Biol. 2008; 40: 815-20.

78. Wu XB, Tao R. Hepatocyte differentiation of mesenchymal stem cells. Hepatobiliary Pancreat Dis Int. 2012; 11: 360-71.

79. Pittenger MF, Mackay AM, Beck SC, Jaiswal RK, Douglas R, Mosca JD, et al. Multilineage potential of adult human mesenchymal stem cells. Science.1999; 284: 143-7.

80. Tchkonia T, Zhu Y, van Deursen J, Campisi J, Kirkland JL. Cellular senescence and the senescent secretory phenotype: therapeutic opportunities. J Clin Invest. 2013; 123: 966-72.

81. Campisi J, d'Adda di Fagagna F. Cellular senescence: when bad things happen to good cells. Nat Rev Mol Cell Biol. 2007; 8: 72940.

82. Suram A, Kaplunov J, Patel PL, Ruan H, Cerutti A, Boccardi V, et al. Oncogene-induced telomere dysfunction enforces cellular senescence in human cancer precursor lesions. EMBO J. 2012; 31: 2839-51.

83. Chen JH, Stoeber K, Kingsbury S, Ozanne SE, Williams GH, Hales $\mathrm{CN}$. Loss of proliferative capacity and induction of senescence in oxidatively stressed human fibroblasts. J Biol Chem. 2004; 279: 49439-46.

84. Courtois-Cox S, Jones SL, Cichowski K. Many roads lead to oncogene-induced senescence. Oncogene. 2008; 27: 2801-9.

85. Braig M, Lee S, Loddenkemper C, Rudolph C, Peters AH, Schlegelberger B, et al. Oncogene-induced senescence as an initial barrier in lymphoma development. Nature. 2005; 436: 660-5.

86. Haigis KM, Sweet-Cordero A. New insights into oncogenic stress. Nat Genet. 2011; 43:177-8.

87. Braig M, Schmitt CA. Oncogene-induced senescence: putting the brakes on tumor development. Cancer Res. 2006; 66: 2881-4.

88. Prieur A, Peeper DS. Cellular senescence in vivo: a barrier to tumorigenesis. Curr Opin Cell Biol. 2008; 20: 150-5.

89. Campisi J. Cellular senescence as a tumor-suppressor mechanism. Trends Cell Biol. 2001; 11: S27-31.

90. Guerra C, Collado M, Navas C, Schuhmacher AJ, Hernández-Porras I, Cañamero M, et al. Pancreatitis-induced inflammation contributes to pancreatic cancer by inhibiting oncogene-induced senescence. Cancer Cell. 2011; 19: 728-39.

91. Jeyapalan JC, Sedivy JM. Cellular senescence and organismal aging. Mech Ageing Dev. 2008; 129: 467-74.

92. Tchkonia T, Morbeck DE, Von Zglinicki T, Van Deursen J, Lustgarten $\mathrm{J}$, Scrable H, et al. Fat tissue, aging, and cellular senescence. Aging Cell. 2010; 9: 667-84.

93. Ksiazek K, Mikula-Pietrasik J, Olijslagers S, Jorres A, von Zglinicki T, Witowski J. Vulnerability to oxidative stress and different patterns of senescence in human peritoneal mesothelial cell strains. Am J Physiol Regul Integr Comp Physiol. 2009; 296: R374-82.

94. Weyemi U, Lagente-Chevallier O, Boufraqech M, Prenois F, Courtin F, Caillou B, et al. ROS-generating NADPH oxidase NOX4 is a critical mediator in oncogenic H-Ras-induced DNA damage and subsequent senescence. Oncogene. 2012; 31: 1117-29.

95. Passos JF, Nelson G, Wang C, Richter T, Simillion C, Proctor CJ, et al. Feedback between p21 and reactive oxygen production is necessary for cell senescence. Mol Syst Biol. 2010; 6: 347. doi: 10.1038/msb.2010.5.

96. Sitte N, Merker K, Von Zglinicki T, Grune T, Davies KJ. Protein oxidation and degradation during cellular senescence of human BJ fibroblasts: part I - effects of proliferative senescence. FASEB J. 2000; 14: 2495-502.

97. Kuilman T, Michaloglou C, Mooi WJ, Peeper DS. The essence of senescence. Genes Dev. 2010; 24: 2463-79.

98. Kuilman T, Michaloglou C, Vredeveld LC, Douma S, van Doorn $\mathrm{R}$, Desmet $\mathrm{CJ}$, et al. Oncogene-induced senescence relayed by an interleukin-dependent inflammatory network. Cell. 2008; 133: 1019-31.

99. Acosta JC, O'Loghlen A, Banito A, Guijarro MV, Augert A, Raguz $\mathrm{S}$, et al. Chemokine signaling via the CXCR2 receptor reinforces senescence. Cell. 2008; 133: 1006-18.

100. Freund A, Orjalo AV, Desprez PY, Campisi J. Inflammatory networks during cellular senescence: causes and consequences. Trends Mol Med. 2010; 16: 238-46.

101. Campisi J, Andersen JK, Kapahi P, Melov S. Cellular senescence: a link between cancer and age-related degenerative disease? Semin Cancer Biol. 2011; 21: 354-9.

102. Rodier F, Campisi J. Four faces of cellular senescence. J Cell Biol. 2011; 192: 547-56.

103. De Cecco M, Jeyapalan J, Zhao X, Tamamori-Adachi M, Sedivy JM. Nuclear protein accumulation in cellular senescence and organismal aging revealed with a novel single-cell resolution fluorescence microscopy assay. Aging (Albany NY). 2011; 3: 955-67.

104. Xue W, Zender L, Miething C, Dickins RA, Hernando E, Krizhanovsky V, et al. Senescence and tumour clearance is triggered by 553 restoration in murine liver carcinomas. Nature. 2007; 445: 656-60.

105. Krizhanovsky V, Yon M, Dickins RA, Hearn S, Simon J, Miething C, et al. Senescence of activated stellate cells limits liver fibrosis. Cell. 2008; 134: 657-67.

106. Coppe JP, Patil CK, Rodier F, Krtolica A, Beauséjour CM, Parrinello $\mathrm{S}$, et al. A human-like senescence-associated secretory phenotype is conserved in mouse cells dependent on physiological oxygen. PLoS One. 2010; 5: e9188. doi: 10.1371/journal.pone.0009188.

107. Coppé JP, Patil CK, Rodier F, Sun Y, Muñoz DP, Goldstein J, et al. Senescence-associated secretory phenotypes reveal cellnonautonomous functions of oncogenic RAS and the p53 tumor suppressor. PLoS Biol. 2008; 6: 2853-68.

108. Rodier F, Coppé JP, Patil CK, Hoeijmakers WA, Muñoz DP, Raza $\mathrm{SR}$, et al. Persistent DNA damage signalling triggers senescenceassociated inflammatory cytokine secretion. Nat Cell Biol. 2009; 11: 973-9.

109. Baker DJ, Wijshake T, Tchkonia T, LeBrasseur NK, Childs BG, van de Sluis B, et al. Clearance of p16Ink4a-positive senescent cells delays ageing-associated disorders. Nature. 2011; 479: 232-6.

110. Kuilman T, Peeper DS. Senescence-messaging secretome: SMS-ing cellular stress. Nature Rev Cancer. 2009; 9: 81-94.

111. Munoz-Espin D, Serrano M. Cellular senescence: from physiology to pathology. Nat Rev Mol Cell Biol. 2014; 15: 482-96.

112. Nagaria P, Robert C, Rassool FV. DNA double-strand break response in stem cells: mechanisms to maintain genomic integrity. Biochim Biophys Acta. 2013; 1830: 2345-53.

113. Beausejour CM, Campisi J. Ageing: balancing regeneration and cancer. Nature. 2006; 443: 404-5.

114. Rodier F, Campisi J. Four faces of cellular senescence. J Cell Biol. 2011; 192: 547-56.

115. Liu Y, Johnson SM, Fedoriw Y, Rogers AB, Yuan H, Krishnamurthy 
$\mathrm{J}$, et al. Expression of p16(ink4a) prevents cancer and promotes aging in lymphocytes. Blood. 2011; 117: 3257-67.

116. Stochaj U, Kodiha M, Shum-Tim D, Colmegna I. Implications of multipotent mesenchymal stromal cell aging. Regen Med. 2013; 8: 211-22.

117. van Deursen JM. The role of senescent cells in ageing. Nature. 2014; 509: 439-46

118. Naylor RM, Baker DJ, van Deursen JM. Senescent cells: a novel therapeutic target for aging and age-related diseases. Clin Pharmacol Ther. 2013; 93: 105-16.

119. Verzola D, Gandolfo MT, Gaetani G, Ferraris A, Mangerini R, Ferrario F, et al. Accelerated senescence in the kidneys of patients with type 2 diabetic nephropathy. Am J Physiol Renal Physiol. 2008; 295: F1563-73.

120. De Cabo R, Carmona-Gutierrez D, Bernier M, Hall MN, Madeo F. The search for antiaging interventions: from elixirs to fasting regimens. Cell. 2014; 157: 1515-26.

121. Willcox BJ, Willcox DC. Caloric restriction, caloric restriction mimetics, and healthy aging in Okinawa: controversies and clinical implications. Curr Opin Clin Nutr Metab Care. 2014; 17: 51-8.

122. Fontana L, Partridge L, Longo VD. Extending healthy life span - from yeast to humans. Science. 2010; 328: 321-6.

123. Haigis MC, Guarente LP. Mammalian sirtuins - emerging roles in physiology, aging, and calorie restriction. Genes Dev. 2006; 20: 2913-21.

124. Hebert AS, Dittenhafer-Reed KE, Yu W, Bailey DJ, Selen ES, Boersma MD, et al. Calorie restriction and SIRT3 trigger global reprogramming of the mitochondrial protein acetylome. Mol Cell. 2013; 49: 186-99.

125. Kahn BB, Alquier T, Carling D, Hardie DG. 2005. AMP-activated protein kinase: ancient energy gauge provides clues to modern understanding of metabolism. Cell Metab. 2005; 1: 15-25.

126. Johnson SM, Rabinovitch PS, Kaeberlein M. mTOR is a key modulator of aging and age-related disease. Nature. 2013; 493: 33845 .

127. Kenyon CJ. The genetics of aging. Nature. 2010; 464: 504-12.

128. Guarente L. Calorei restriction and sirtuins revisited. Gen Dev. 2013; 27: 2072-85

129. Rodgers JT, Lerin C, Haas W, Gygi SP, Spiegelman BM, Puigserver P. Nutrient control of glucose homeostasis through a complex of PGC-1alpha and SIRT1. Nature. 2005; 434: 113-8.

130. Gerhart-Hines Z, Rodgers JT, Bare O, Lerin C, Kim SH, Mostoslavsky $\mathrm{R}$, et al. Metabolic control of muscle mitochondrial function and fatty acid oxidation through SIRT1/PGC-1alpha. EMBO J. 2007; 26: 1913-23.

131. Brunet A, Sweeney LB, Sturgill JF, Chua KF, Greer PL, Lin Y, et al. Stress-dependent regulation of FOXO transcription factors by the SIRT1 deacetylase. Science. 2004; 303: 2011-5.

132. Motta MC, Divecha N, Lemieux M, Kamel C, Chen D, Gu W, et al. Mammalian SIRT1 represses forkhead transcription factors. Cell. 2004; 116: 551-63.

133. Purushotham A, Schug TT, Xu Q, Surapureddi S, Guo X, Li X. Hepatocyte-specific deletion of SIRT1 alters fatty acid metabolism and results in hepatic steatosis and inflammation. Cell Metab. 2009; 9: $327-38$

134. Feige JN, Lagouge M, Canto C, Strehle A, Houten SM, Milne JC, et al. Specific SIRT1 activation mimics low energy levels and protects against diet-induced metabolic disorders by enhancing fat oxidation. Cell Metab. 2008; 8: 347-58

135. Fulco M, Cen Y, Zhao P, Hoffman EP, McBurney MW, Sauve AA, et al. Glucose restriction inhibits skeletal myoblast differentiation by activating SIRT1 through AMPK-mediated regulation of Nampt.
Dev Cell. 2008; 14: 661-73.

136. Canto C, Gerhart-Hines Z, Feige JN, Lagouge M, Noriega L, Milne JC, et al. AMPK regulates energy expenditure by modulating NAD+ metabolism and SIRT1 activity. Nature. 2009; 458: 1056-60.

137. Canto C, Jiang LQ, Deshmukh AS, Mataki C, Coste A, Lagouge M, et al. Interdependence of AMPK and SIRT1 for metabolic adaptation to fasting and exercise in skeletal muscle. Cell Metab. 2010; 11: 213-9.

138. Hou X, Xu S, Maitland-Toolan KA, Sato K, Jiang B, Ido Y, et al. SIRT1 regulates hepatocyte lipid metabolism through activating AMP-activated protein kinase. J Biol Chem. 2008; 283: 20015-26.

139. Lan F, Cacicedo JM, Ruderman N, Ido Y. SIRT1 modulation of the acetylation status, cytosolic localization, and activity of LKB1. Possible role in AMP-activated protein kinase activation. J Biol Chem. 2008; 283: 27628-35.

140. Hallows WC, Yu W, Denu JM. Regulation of glycolytic enzyme phosphoglycerate mutase-1 by Sirt1 protein-mediated deacetylation. J Biol Chem. 2012; 287: 3850-8.

141. Lim JH, Lee YM, Chun YS, Chen J, Kim JE, Park JW. Sirtuin 1 modulates cellular responses to hypoxia by deacetylating hypoxiainducible factor 1alpha. Mol Cell. 2010; 38: 864-78.

142. Adler AS, Sinha S, Kawahara TL, Zhang JY, Segal E, Chang HY. Motif module map reveals enforcement of aging by continual NFkappaB activity. Genes Dev. 2007; 21: 3244-57.

143. Asher G, Gatfield D, Stratmann M, Reinke H, Dibner C, Kreppel F, at al. SIRT1 regulates circadian clock gene expression through PER2 deacetylation. Cell. 2008; 134: 317-28.

144. Nakahata Y, Kaluzova M, Grimaldi B, Sahar S, Hirayama J, Chen D, et al. The NAD+-dependent deacetylase SIRT1 modulates CLOCKmediated chromatin remodeling and circadian control. Cell. 2008; 134: $329-40$

145. Nakahata Y, Sahar S, Astarita G, Kaluzova M, Sassone-Corsi P. Circadian control of the NAD+ salvage pathway by CLOCKSIRT1. Science. 2009; 324: 654-7.

146. Ramsey KM, Yoshino J, Brace CS, Abrassart D, Kobayashi Y, Marcheva B, et al. Circadian clock feedback cycle through NAMPTmediated NAD+ biosynthesis. Science. 2009; 324: 651-4.

147. Chang HC, Guarente L. SIRT1 mediates central circadian control in the SCN by a mechanism that decays with aging. Cell. 2013; 153 1448-60.

148. Valentinuzzi VS, Scarbrough K, Takahashi JS, Turek FW. Effects of aging on the circadian rhythm of wheel-running activity in C57BL/6 mice. Am J Physiol. 1997; 273: R1957-64.

149. Howitz KT, Bitterman KJ, Cohen HY, Lamming DW, Lavu S, Wood JG, et al. Small molecule activators of sirtuins extend Saccharomyces cerevisiae lifespan. Nature. 2003; 425: 191-6.

150. Jimenez-Gomez Y, Mattison JA, Pearson KJ, Martin-Montalvo A, Palacios HH, Sossong AM, et al. Resveratrol improves adipose insulin signaling and reduces the inflammatory response in adipose tissue of rhesus monkeys on high-fat, high-sugar diet. Cell Metab. 2013; 18: 533-45.

151. Fiori JL, Shin YK, Kim W, Krzysik-Walker SM, González-Mariscal I, Carlson OD, et al. Resveratrol prevents beta-cell dedifferentiation in nonhuman primates given a high-fat/high-sugar diet. Diabetes. 2013; 62: 3500-13

152. Mattison JA, Wang M, Bernier M, Zhang J, Park SS, Maudsley S, et al. Resveratrol prevents high fat/sucrose diet-induced central arterial wall inflammation and stiffening in nonhuman primates. Cell Metab. 2014; 20: 183-90.

153. Baur JA, Pearson KJ, Price NL, Jamieson HA, Lerin C, Kalra A, et al. Resveratrol improves health and survival of mice on a high-calorie diet. Nature. 2006; 444: 337-42. 
154. Bauer JH, Goupil S, Garber GB, Helfand SL. An accelerated assay for the identification of lifespan-extending interventions in Drosophila melanogaster. Proc Natl Acad Sci USA. 2004; 101: 12980-5.

155. Baur JA, Sinclair DA. Therapeutic potential of resveratrol: the in vivo evidence. Nat Rev Drug Discov. 2006; 5: 493-506.

156. Timmers S, Auwerx J, Schrauwen P. The journey of resveratrol from yeast to human. Aging (Albany NY). 2012; 4: 146-58.

157. Lagouge M, Argmann C, Gerhart-Hines Z, Meziane H, Lerin C, Daussin F, et al. Resveratrol improves mitochondrial function and protects against metabolic disease by activating SIRT1 and PGC1alpha. Cell. 2006; 127: 1109-22.

158. Beher D, Wu J, Cumine S, Kim KW, Lu SC, Atangan L, et al. Resveratrol is not a direct activator of SIRT1 enzyme activity. Chem Biol Drug Des. 2009; 74: 619-24.

159. Kaeberlein M, McVey M, Guarente L. The SIR2/3/4 complex and SIR2 alone promote longevity in Saccharomyces cerevisiae by two different mechanisms. Genes Dev. 1999; 13: 2570-80.

160. Mouchiroud L, Houtkooper RH, Moullan N, Katsyuba E, Ryu D, Cantó C, et al. The NAD $(+) /$ Sirtuin Pathway Modulates Longevity through Activation of Mitochondrial UPR and FOXO Signaling. Cell . 2013; 154: 430-41.

161. Oh J, Lee YD, Wagers AJ. Stem cell aging: mechanisms, regulators and therapeutic opportunities. Nat Med. 2014; 20: 870-80.

162. Passier R, Mummery C. Origin and use of embryonic and adult stem cells in differentiation and tissue repair. Cardiovasc Res. 2003; 58: 324-35.

163. Mimeault M, Hauke R, Batra SK. Stem cells: a revolution in therapeutics-recent advances in stem cell biology and their therapeutic applications in regenerative medicine and cancer therapies. Clin Pharmacol Ther. 2007; 82: 252-64.
164. Saini A, Mastana S, Myers F, Lewis MP. 'From death, lead me to immortality'-Mantra of ageing skeletal muscle. Curr Genomics. 2013; 14: 256-67.

165. Brack AS, Conboy MJ, Roy S, Lee M, Kuo CJ, Keller C, et al. Increased Wnt signaling during aging alters muscle stem cell fate and increases fibrosis. Science. 2007; 317: 807-10.

166. Rodier F, Coppé JP, Patil CK, Hoeijmakers WA, Muñoz DP, Raza $\mathrm{SR}$, et al. Persistent DNA damage signalling triggers senescenceassociated inflammatory cytokine secretion. Nat Cell Biol. 2009; 11: 973-9.

167. Kuhn HG, Dickinson-Anson H, Gage FH. Neurogenesis in the dentate gyrus of the adult rat: age-related decrease of neuronal progenitor proliferation. J Neurosci. 1996; 16: 2027-33.

168. Maslov AY, Barone TA, Plunkett RJ, Pruitt SC. Neural stem cell detection, characterization, and age-related changes in the subventricular zone of mice. J Neurosci. 2004; 24: 1726-33.

169. Seib DR, Corsini NS, Ellwanger K, Plaas C, Mateos A, Pitzer C, et al. Loss of Dickkopf-1 restores neurogenesis in old age and counteracts cognitive decline. Cell Stem Cell. 2013; 12: 204-14.

170. Balaban RS, Nemoto S, Finkel T. Mitochondria, oxidants, and aging. Cell. 2005; 120: 483-95.

171. Karpac J, Jasper H. Aging: seeking mitonuclear balance. Cell. 2013; 154: 271-3.

172. Hubbard BP, Gomes AP, Dai H, Li J, Case AW, Considine T, et al. Evidence for a common mechanism of SIRT1 regulation by allosteric activators. Science. 2013; 339: 1216-9.

173. Dai H, Kustigian L, Carney D, Case A, Considine T, Hubbard BP, et al. SIRT1 activation by small molecules: kinetic and biophysical evidence for direct interaction of enzyme and activator. J Biol Chem. 2010; 285: 32695-703. 